\title{
A Case of Neuroleptic Malignant Syndrome with Quetiapine from Iran
}

Bidaki R*, Boshrabadi AR and Mansoori M

Rafsanjan University of Medical Sciences, Iran

\begin{abstract}
To report a case of neuroleptic malignant syndrome (NMS) acutely, secondary to low dose quetiapine in a old man. Clinicians should be aware that NMS with single dose of quetiapine is possible.
\end{abstract}

Keywords: Neuroleptic Malignant Syndrome (NMS); Quetiapine; Iran

\section{Case Presentation}

A 66-year-old white male admitted in Emergency Department with a temperature of $39.3^{\circ} \mathrm{C}$, dysphagia, aphasia, decreased level of consciousness, masked face, rigidity, urinary incontinence and mutism. Differential diagnoses included aspiration, stroke, hepatic and renal encephalopathy, cerebrovascular accident and infection. His Glasgow Coma Scale (GCS) score was 10. As soon as these were excluded, NMS was considered. He had a history of mild dementia Alzheimer. Medications were quetiapine $25 \mathrm{mg}$ and clonazepam 1 $\mathrm{mg}$ and propranolol $20 \mathrm{mg}$ b.i.d. Since starting quetiapine, he had had temperatures to 39.3 , bradycardia, brady kinesia one week previously, she had had a Creatine Phosphokinase (CPK) level of 442 at first and 760 in next laboratory test. He was admitted in internal ward of hospital.

Blood pressure was normal; pulse was $55 \mathrm{bpm}$. Head CT was normal. Because of this, head MRI was done and it showed, age related atrophy and mild ventricles dilation noted, no mass, hemorrhage or shift is seen, a few T2 FLAIR hypersignal foci in both cerebral hemispheres due to arteriolosclerotic change. Cerebellum, CP angle and 7-8th nerve root complexes are normal. Mild right side mastoiditis is noted. Left lens is not seen. Chest X-ray was normal. Arterial blood gases showed: $\mathrm{pH}=7.325, \mathrm{PCO} 2=40.8, \mathrm{PO} 2=78.9, \mathrm{O} 2$ Saturation $=$ 94.1, $\mathrm{HCO} 3=20.6, \mathrm{BE}=-4.7, \mathrm{BE}$ ecf $=-4.5, \mathrm{BB}=43.2$.

In this case, concomitant administration of quetiapine and propranolol caused neuroleptic malignant syndrome.

\section{Discussion}

DSM-IV-TR research criteria for NMS include "severe muscle rigidity and elevated temperature associated with the use of antipsychotics and two or more of the following: diaphoresis, dysphagia, tremor, incontinence, changes in consciousness, mutism, tachycardia, elevated or labile blood pressure, leukocytosis, and laboratory evidence of muscle injury (e.g., increased CPK and myoglobulinuria) [1]

With the novel antipsychotics, the risk of NMS is likely decreased, but this remains probable [2,3]. Neuroleptic malignant syndrome is induced less by atypical antipsychotics.

The case of NMS presented here accompanies 14 others regarding quetiapine, an atypical antipsychotic brought to market in 1997. Cases were identified through searches of MEDLINE/PubMed (1950-2011) and Iowa Drug Information Services (1966-2011).

NMS was introduced in French medical literature in 1960 primarily. Delay and Deniker named the disorder in 1968. According to DSMIV, an essential feature of NMS is the "development of severe muscle rigidity and elevated temperature in an individual using a neuroleptic medication" [1]. These features must be accompanied by 2 or more of the following symptoms: diaphoresis, tremor, dysphagia, incontinence, changes in consciousness, mutism, tachycardia or changes in blood pressure, leukocytosis, and evidence of muscle injury. NMS is believed to occur more frequently with high-potency neuroleptics (typical antipsychotics) than with low-potency or atypical antipsychotics due to a drug's mechanism of action. Convient antipsychotics block dopamine (D2) receptors, whereas new antipsychotics have greater antagonism for serotonin receptors than for dopamine receptors [4]. Due to this difference in their affinity for dopamine receptors, patients receiving typical antipsychotics have a greater risk of developing extrapyramidal symptoms.

CNS disorders to be considered in the differential diagnosis include infection, acute lethal catatonia, seizures, Parkinson's disease, hepatic and renal encephalopathy, and cerebrovascular accident. Systemic disorders to consider include sepsis, thyrotoxicosis, pheochromocytoma, tetany, and acute porphyria. In addition, several adverse drug reactions must be considered such as malignant hyperthermia, anticholinergic delirium, antipsychotic-induced heat stroke, lithium toxicity, strychnine poisoning, heavy metal poisoning, serotonergic syndrome, illicit drug ingestion (eg, amphetamines, phencyclidine), and withdrawal states from alcohol or benzodiazepines [5-7].

Atypical NMS has been defined as less severe than that seen with conventional antipsychotics. Symptoms include fewer extrapyramidal symptoms, smaller increases in $\mathrm{CK}$, less muscle rigidity, and lower fever [8].

\section{Treatment}

Approximately $63 \%$ of patients with NMS resolve within 1 week of, and almost all recover within 1 month [9].

As soon as NMS is suspected in a patient, antipsychotic therapy was been withheld. Dantrolene was been used to treat symptoms of muscle rigidity. Hydration is especially critical in this patient population to avoid renal failure secondary to development of rhabdomyolysis [10].

*Corresponding author: Bidaki R, Assistant Professor, Rafsanjan University of Medical Sciences, Iran, Tel: (+98)3915230081; Fax: (+98)3915230082; E-mail: REZA_BIDAKI@yahoo.com

Received November 10, 2011; Accepted May 30, 2012; Published June 04, 2012

Citation: Bidaki R, Boshrabadi AR, Mansoori M (2012) A Case of Neuroleptic Malignant Syndrome with Quetiapine from Iran. JAller Ther 3:117. doi:10.4172/21556121.1000117

Copyright: ( 2012 Bidaki R, et al. This is an open-access article distributed unde the terms of the Creative Commons Attribution License, which permits unrestricted use, distribution, and reproduction in any medium, provided the original author and source are credited. 
Citation: Bidaki R, Boshrabadi AR, Mansoori M (2012) A Case of Neuroleptic Malignant Syndrome with Quetiapine from Iran. J Aller Ther 3:117. doi:10.4172/2155-6121.1000117

Page 2 of 2

Supportive care for patients with NMS includes cooling blankets, venous thromboembolism prophylaxis, and mechanical ventilation if breathing is impaired by muscle rigidity [11]. The dopamine agonist bromocriptine, was administered 2 times daily at beginning with doses of $2.5 \mathrm{mg}$ and was increased up to $5 \mathrm{mg} 2$ times daily, the antiviral agent amantadine at dose of $100 \mathrm{mg}$ twice daily.

\section{References}

1. American Psychiatric Association (2000) Diagnostic and Statistical Manua of Mental Disorders, DSM-1V-TR. 4th edition, text revision. Washington, DC, American Psychiatric Association: 798.

2. Caroff SN, Mann SC, Campbell EC (2000) Atypical antipsychotics and neuroleptic malignant syndrome. Psychiatric Annals 30: 314-321.

3. Hasan S, Buckley P (1998) Novel antipsychotics and the neuroleptic malignant syndrome: a review and critique. Am J Psychiatry 155: 1113-1116.

4. Kelly K, Weiner E (2008) Schizophrenia. In: Chisholm-Burns M, Wells BG Schwinghammer $\mathrm{T}$, et al. (eds). Pharmacotherapy principles and practice. (1stedn). New York: McGraw-Hill Co: 549-68.
5. Wargo KA, Gupta R (2005) Neuroleptic malignant syndrome: no longer exclusively a "neuroleptics" phenomenon. J Pharm Technol 21: 262-270.

6. al-Waneen R (2000) Neuroleptic malignant syndrome associated with quetiapine. Can J Psychiatry 45: 764-765.

7. Pelonero AL, Levenson JL, Pandurangi AK (1998) Neuroleptic malignant syndrome: a review. Psychiatr Serv 49: 1163-1172.

8. Karagianis JL, Phillips LC, Hogan KP, LeDrew KK (1999) Clozapine-associated neuroleptic malignant syndrome: two new cases and a review of the literature. Ann Pharmacother 33: 623-630.

9. Caroff SN, Mann SC, Campbell EC, Sullivan KA, Obeso J (2001) Neuroleptic malignant syndrome. Adverse Drug React Bull 209: 799-802.

10. Adnet $P$, Lestavel $P$, Krivosic-Horber $R$ (2000) Neuroleptic malignant syndrome Br J Anaesth 85: 129-135.

11. Najib J (1997) Neuroleptic malignant syndrome: a case report and review of the treatment. Hosp Pharm 32: 512-518. 